Crowley, N. (1951). J. gen. Microbiol. 5, 239-249.

\title{
Polysaccharidases of Group A Streptococci
}

\author{
BY NUALA CROWLEY \\ Bacteriology Department, The Royal Free Hospital, London
}

\begin{abstract}
SUMMARY : Proteinase produced by Group A streptococei was associated with a decrease in hyaluronidase production which was not related to any other known environmental condition. The concentration of proteinase which was correlated with decreased hyaluronidase production was constant for a given strain. Inactive polysaccharidase components in cell-free filtrates were converted to active form by a number of different agents, namely, sodium sulphite, zinc and calcium ions, autoclaved broth and pantothenic acid. Bacterial dextran, pectin and inulin were depolymerized by cell-free filtrates and by partially purified enzymes derived from Type 4, Type 22 and Type 2 strains. 'Depolymerase' was associated with hyaluronidase and amylase in biologically active material prepared by fractional precipitation.
\end{abstract}

Degradation of starch by hyaluronidase-positive strains of Group A streptococci was described by Crowley (1950), who found that environmental conditions unfavourable for active proteinase production also influenced polysaccharidase activity. The present paper reports further studies of polysaccharidase activity related to the possibility of an inactive precursor analogous to that of proteinase (Elliott \& Dole, 1947) and to the hypothesis that depolymerization of viscous substances by Group A streptococci may be the function of one or more enzymes of low specificity.

\section{MATERIAL AND METHODS}

Strains. The strains of Group A streptococci were those used by Crowley (1950) in studying amylolytic activity. Type-specific $M$ antigens were identified by the method of Swift, Wilson \& Lancefield (1943), and T antigens by slide agglutination (Griffith, 1934).

Cultures. Strains were grown in the same batches of glucose beef infusion broth or in soft agar gels as used for amylase production (Crowley, 1950).

Proteinase. The clotting time of milk + thiolacetate was estimated by the method of Elliott \& Dole (1947).

Hyaluronidase. Hyaluronidase was titrated by the M.C.P. test (McClean, 1942). Pooled cadaver synovial fluid kept under toluene was used as substrate. The hyaluronic acid content of the original pool was $1 \%$, estimated by Dr W. T. J. Morgan (The Lister Institute, Chelsea). This batch was standardized

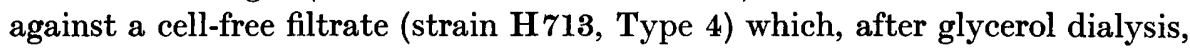
was preserved at $-10^{\circ}$ and subsequently used to standardize fresh batches of substrate. Synovial fluid formed mucin clot with $2 \mathrm{~N}$ acetic acid without the addition of extra protein. Horse serum was only added for purposes of comparison with six batches of umbilical hyaluronate prepared in this and other laboratories. No sample of synovial fluid from the pool gave discrepant results like those obtained with different batches of partially purified umbilical hyaluronate.

Amylase. Hydrolysis of $\mathbf{0 \cdot 2} \%$ starch (AnalaR) was tested by the method of 
Crowley (1950), but using $0.5 \mathrm{ml}$. of substrate instead of $1.0 \mathrm{ml}$., thus enabling readings to be made at shorter time-intervals. Starches of different grain sizes (wheat, maize, arrowroot, potato, rice and tapioca) were supplied by Messrs Reckitt and Colman, Carrow Works, Norwich, and by British Drug Houses Ltd. Both $0 \cdot 2 \%(w / v)$ and $1 \%(w / v)$ gels were tested.

Depolymerase. Citrus pectin (Messrs Reckitt and Colman), inulin (Messrs Kerfoot), and bacterial dextran from Leuconostoc mesenteroides (East Anglia Chemical Co. Ltd.) were used to test depolymerizing activity. Ethanol, methanol or acetone (AnalaR) were used in preliminary tests to determine the optimal concentrations, $\mathrm{pH}$ values and volumes of precipitants suitable to produce a characteristic substrate reaction. The reagents are shown in Table 1, together with physical changes seen by naked eye in substrates undergoing degradation. In all tests $\mathbf{0 . 5} \mathrm{ml}$. substrate in sodium $\beta$-glycerophosphate $(0.126 \mathrm{M})$ was mixed with $0.5 \mathrm{ml}$. aqueous dilution of enzyme sample and incubated in a $37^{\circ}$ water-bath. The protein in low dilutions of broth interfered with readings in all depolymerase tests, therefore broth dilutions of less than 1/10 were treated with acid-ethanol (95 parts ethanol +5 parts $\mathrm{N}-\mathrm{HCl}$ ) and after centrifuging to remove precipitate the supernatant fluids were pipetted into acetone, methanol or ethanol at appropriate $\mathrm{pH}$. The lowest dilution of the sample + substrate mixture was tested for reducing sugars or for fructose (furfural test) after incubation, and compared with a broth + substrate control.

Units. Working with twofold dilutions in the defined conditions $0.5 \mathrm{ml}$. of enzyme dilution in the end-point tube contained 1 unit of enzyme, therefore $1 \mathrm{ml}$. of the original sample contained 2 units $\times$ the reciprocal of the end-point. With starch substrates the unit was equivalent to the Wohlegemuth unit for pancreatic diastase, and with hyaluronate to the M.C.P. unit of Quinn (1948).

Partially purified enzymes. After preliminary precipitation by salt saturation, protein fractions were treated with varied concentrations of ethanol or methanol at $-10^{\circ}$ and different $\mathrm{pH}$ values. Further purification was attempted by fructional precipitation in methanol + water mixtures following the principle of Wittler \& Pillemer (1949).

\section{EXPERIMENTAL}

\section{Conditions decreasing hyaluronidase production}

Cultural conditions. The pattern of hyaluronidase production in a favourable broth was constant for any one strain but showed considerable strain variation. The usual strain pattern was established in Neo-peptone autoclaved broth cultures incubated at $37^{\circ}$ for $4-6$ days. The combined effects of varying the brand of peptone and the method of sterilization of the buffered beef infusion broth are shown in Fig. 1, together with the period of incubation, and the effect of growth at $23^{\circ}$. This experiment was described when reporting the effect of cultural conditions on amylase production by the same strain, and results for the two enzymes run parallel. Consistent results were obtained with batches of broth made from eight separate lots of beef. Type 22 strains showed similar alterations of hyaluronidase activity. 
The results suggested the existence of a heat-labile growth-promoting factor in filtered broth, enhanced by Proteose peptone in cultures grown at $23^{\circ}$ because this medium contained the greatest number of viable organisms for the longest time. On the other hand, profuse growth occurred in all the broth cultures, and it seemed possible that there was an enzyme-promoting factor in autoclaved broth which converted inactive precursor to active hyaluronidase or initiated an autocatalytic process analogous to the production of active proteinase (Elliott \& Dole, 1947).
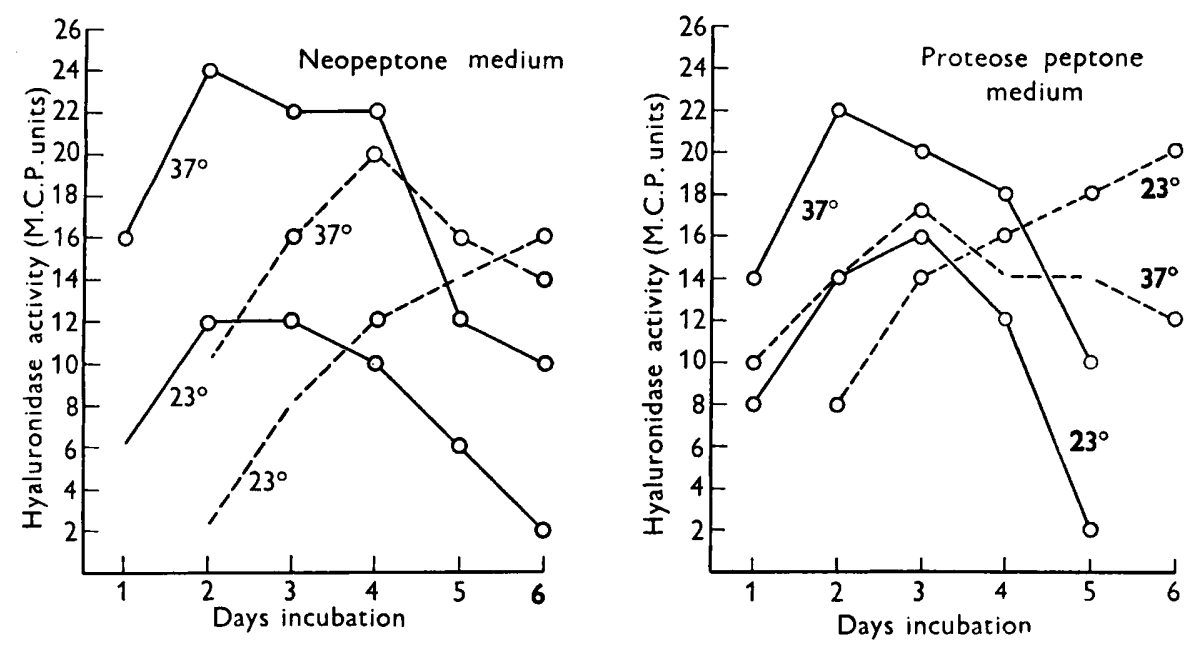

Fig. 1. Changes in hyaluronidase production in varied culture conditions. Strain $\mathbf{H} \mathbf{r 1 3}$, Type 4 was grown in four different broths, in duplicate cultures incubated at $23^{\circ}$ and $37^{\circ}$. Daily samples were frozen, hyalứnidase titrations being made when sets were complete, against the same batch of substrate. ___, autoclaved broth; ....., filtered broth.

Effect of proteinase. Two strains, H713 Type 4 and 63T Type 22, were grown in eight differently constituted soft agar gels. The gels were made up with different amounts of agar and various types of broth (see Fig. 1). In each series, two gels contained bicarbonate buffer, instead of sodium $\beta$-glycerophosphate, and one gel contained filtered broth. After 2 days incubation at $37^{\circ}$ the cultures were frozen and the liquid thawed out and filtered. High proteinase concentration was correlated with increased agar/broth volume ratio, irrespective of the original broth constituents. The greatest yield of proteinase by one strain was in the medium made up with Neopeptone autoclaved broth most favourable for hyaluronidase production, mixed with $1.5 \mathrm{vol}$. agar. $\log t$, the time in minutes taken to clot milk + thiolacetate, was plotted against $\log c$, using twofold dilutions of enzyme sample. Results for a Type 4 strain (Fig. 2) show that a final high proteinase concentration was associated with twofold decrease in hyaluronidase unit value. Results for the Type 22 strain were similar.

Five Type 4 and five Type 22 strains were selected which showed wide variation in hyaluronidase and proteinase production. The ten strains were 
grown in soft agar containing broth favourable for proteinase production. The hyaluronidase titre of two strains which did not produce proteinase was undiminished. Six strains produced high proteinase concentration, and the usual hyaluronidase titre was halved. Two strongly proteinase-positive Type 4 strains produced no hyaluronidase in these conditions, both strains usually showing low M.C.P. titre. The effect of high proteinase concentration on Type 4 hyaluronidase was greater than the effect on Type 22 hyaluronidase, the proteinase concentration needed to halve the hyaluronidase titre being higher than the corresponding value for Type 4 strains.

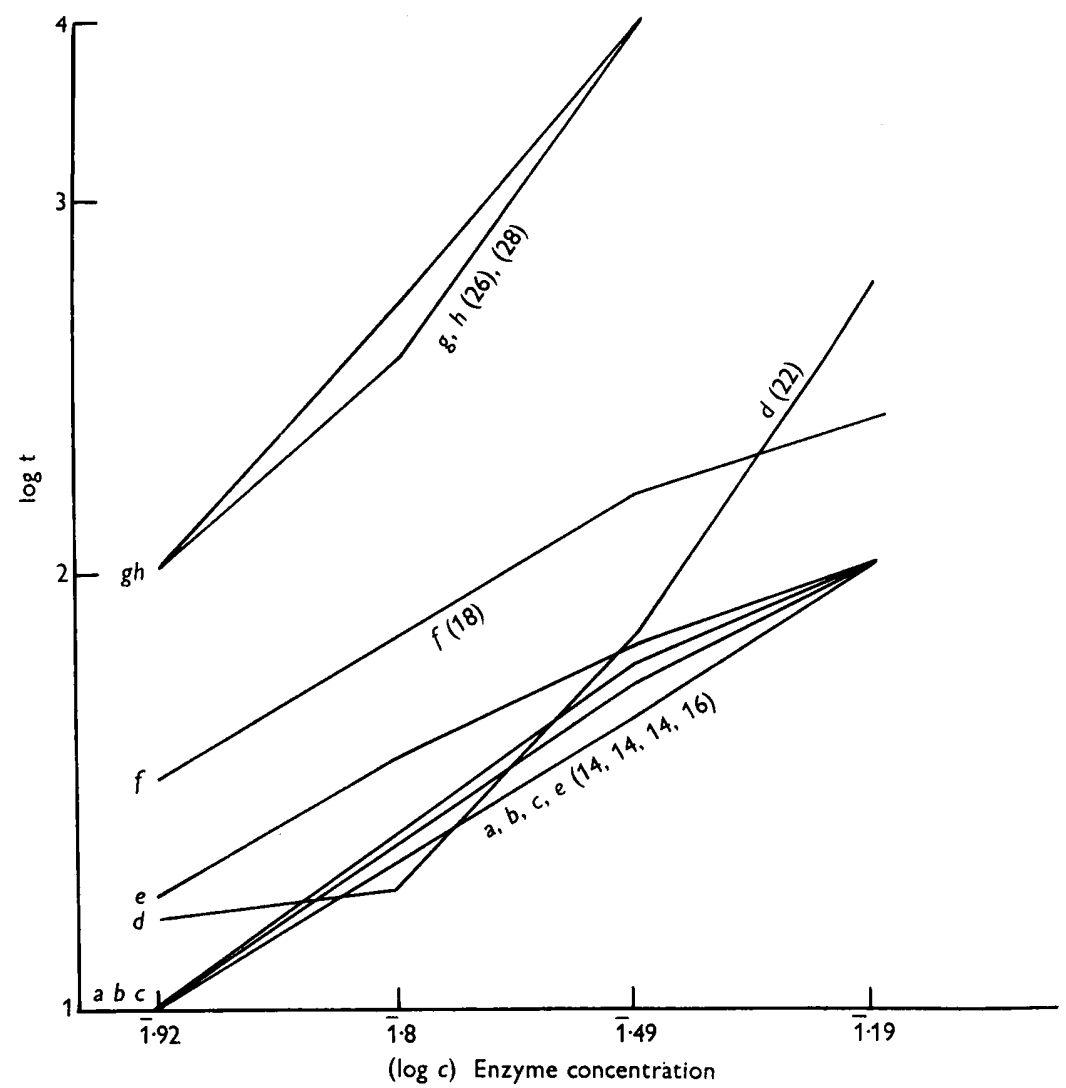

Fig. 2. The hyaluronidase titre of strain $\mathbf{H r 1 3}$, Type 4, in different cultures containing different proteinase concentrations. Letters $a-h=$ different cultures in varied media; numbers in brackets $=$ hyaluronidase titre in M.C.P. units. Log $t=$ time in min. taken to clot milk + thiolacetate. The concentration of enzyme in dilutions less than $1 / 12$ was too high to take minute readings.

High proteinase yields were also associated with decreased $\alpha$-amylase-like activity of hyaluronidase positive Type 4 strains. The $\beta$-amylase-like activity of the same strains, mainly catalysing viscosity diminution and partial degradation of starch, was not decreased. The viscosity-decreasing component predominates in Type 22 hyaluronidase (see p. 247). There is at present no evidence to explain the proteinase effect. 


\section{Degradation of other polysaccharides}

Polysaccharide substrates. The characteristic reactions of control solutions precipitated with ethanol, methanol or acetone are shown in Table 1.

\section{Table 1. Tests for degradation of polysaccharides}

All solutions were in sodium $\beta$-glycerophosphate $0 \cdot 126 \mathrm{M}, \mathrm{pH} 7 \cdot 4$.

Incubation $37^{\circ}$ water-bath: Dextran $18 \mathrm{hr}$.; starches $30 \mathrm{~min}$. and $18 \mathrm{hr}$; pectin $1 \mathrm{hr}$; hyaluronic acid $20 \mathrm{~min}$.; inulin $2 \mathrm{hr}$. and $18 \mathrm{hr}$.

Viscosity decrease qualitative test. Rate of filtration through No. 50 Whatman paper as compared with control solution (higher concentration).

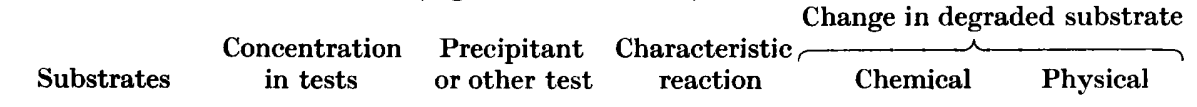

Glucose polymers:

$\begin{array}{ccccc}\text { Dextran } & 3,1 \%(\mathrm{v} / \mathrm{v}) & \begin{array}{c}\text { Methanol } \\ 0 \cdot 3 \mathrm{ml} .\end{array} & \text { Clotted ppt. } & \begin{array}{c}\text { Increased tur- Floccules } \\ \text { bidity } \rightarrow \text { clear } \\ \text { solution }\end{array} \\ \text { Starch } & \begin{array}{c}0.5,0 \cdot 1 \% \\ (\mathrm{w} / \mathrm{v})\end{array} & \text { Iodine } & \begin{array}{c}\text { Colour } \\ \text { change }\end{array} & \begin{array}{c}\text { Colour reading Floccules, } \\ \text { loss of } \\ \text { viscosity }\end{array}\end{array}$

Fructose polymer:

\begin{tabular}{|c|c|c|c|c|c|}
\hline Inulin & $1 \%(w / v)$ & $\begin{array}{l}\text { Acetone } \\
0.5 \mathrm{ml} ., \\
\text { pH 8.0 }\end{array}$ & $\begin{array}{l}\text { Uniform } \\
\text { turbidity }\end{array}$ & $\begin{array}{l}\text { Increased tur- } \\
\text { bidity } \rightarrow \text { clear } \\
\text { solution }\end{array}$ & $\begin{array}{l}\text { Opalescence } \\
\text { fine deposi }\end{array}$ \\
\hline \multicolumn{6}{|c|}{ falacturonic acid polymer: } \\
\hline Pectin & $\begin{array}{l}0 \cdot 5,0 \cdot 1 \% \\
(w / v)\end{array}$ & $\begin{array}{l}\text { Acetone } 1 \mathrm{ml} \text {, } \\
\text { pH } 7 \cdot 4\end{array}$ & Clot & $\begin{array}{l}\text { Clot pre- } \\
\text { vention }\end{array}$ & $\begin{array}{l}\text { Loss of } \\
\text { viscosity }\end{array}$ \\
\hline \multicolumn{6}{|c|}{ Iucopolysaccharide: } \\
\hline $\begin{array}{l}\text { Hyaluronic } \\
\text { acid }\end{array}$ & $0.2 \%(v / v)$ & $\begin{array}{l}2 \mathrm{~N} \text { acetic } \\
\text { acid, } 0 \cdot 2 \mathrm{ml} \text {. }\end{array}$ & Clot & $\begin{array}{l}\text { Clot pre- } \\
\text { vention, in- } \\
\text { creased } \\
\text { turbidity }\end{array}$ & $\begin{array}{l}\text { Loss of } \\
\text { viscosity }\end{array}$ \\
\hline
\end{tabular}

Physical changes were easier to see in high substrate concentrations, whereas chemical changes were best seen in lower concentrations using minimal volume of precipitant. Buffered pectin solutions formed a clot with acetone at $\mathrm{pH} \mathbf{7 \cdot 4}$ resembling the mucin-clot of hyaluronic acid + protein. Pectin-clot prevention tests were carried out in the manner of M.C.P. tests. Bacterial dextran was precipitated in irregular clumps by $0.3 \mathrm{ml}$. methanol at $\mathrm{pH} 8.0$ without turbidity, but a further $0.1 \mathrm{ml}$. of methanol caused general turbidity. Change in inulin was estimated by increase or decrease in turbidity, together with furfural tests for fructose.

Degradation by culture supernatants, cell-free filtrates and partially purified enzymes. Results with Type 4, Type 22 and Type 2 strains are shown in Table 2. Loss of viscosity was the earliest change in starch and pectin solutions. Opalescence appeared in degraded inulin solutions and coarse floccules in dextran, which became finer after further incubation. Floccules did not appear when the test was carried out at $\mathrm{pH}$ value 6.6 but were seen better at $\mathrm{pH}$ range $7 \cdot 4-7 \cdot 8$, than at $\mathrm{pH} 7 \cdot 0$. All reactions were retarded in the absence of phosphate; the optimal $\mathrm{NaCl}$ concentration was not determined. In general the same 
cultural conditions affected production of depolymerase, amylase and hyaluronidase, but full investigation was not attempted nor have enough representative serological types been tested to form any opinion of the value of screening tests in the estimation of depolymerizing activity by strains other than Types 4 , 22 or 2.

\section{Table 2. Degradation of polysaccharides by extracellular enzymes of Group A streptococci}

All solutions were in sodium $\beta$-glycerophosphate buffer $(0 \cdot 126 \mathrm{M})$, except hyaluronic acid (pooled cadaver synovial fluid). Tests for degradation as in Table 1 . Readings $++=$ high titres recorded; $+=$ low titres recorded; $\pm=1 / 8$ dilution only. Results for partially purified material were based on unit activity $/ \mathrm{mg}$. protein nitrogen. Starches: high $\%$ amylose $(24 \%)=$ soluble, wheat; low \% amylose $(17 \%)=$ arrowroot, rice, tapioca.

\begin{tabular}{|c|c|c|c|c|c|c|c|}
\hline \multirow[b]{2}{*}{$\begin{array}{l}\text { Cell free } \\
\text { filtrates }\end{array}$} & \multirow[b]{2}{*}{$\begin{array}{l}\quad \text { Strains } \\
\text { H713 Type } 4 \\
\text { 63T Type } 22 \\
\text { 4226 Type } 2\end{array}$} & \multicolumn{6}{|c|}{ Substrates } \\
\hline & & $\begin{array}{c}\text { Hyal- } \\
\text { uronic } \\
\text { acid } \\
++ \\
++ \\
\text {. }\end{array}$ & $\begin{array}{c}\text { Starch } \\
\text { high \% } \\
\text { amylose } \\
++ \\
\dot{+} \\
+\end{array}$ & $\begin{array}{c}\text { Starch } \\
\text { low \% } \\
\text { amylose } \\
++ \\
\pm^{*} \\
+\end{array}$ & $\begin{array}{c}\text { Bac- } \\
\text { terial } \\
\text { dextran } \\
+ \\
+ \\
\pm\end{array}$ & $\begin{array}{c}\text { Citrus } \\
\text { pectin } \\
+ \\
+ \\
+\end{array}$ & $\begin{array}{c}\text { Inulin } \\
++ \\
+ \\
\pm\end{array}$ \\
\hline $\begin{array}{l}\text { Partially } \\
\text { purified } \\
\text { enzymes }\end{array}$ & $\begin{array}{l}\text { Type } 4,5 \text { strains } \\
\text { Type 22, } 3 \text { strains } \\
\text { Type } 2\end{array}$ & $\begin{array}{l}++ \\
++ \\
\end{array}$ & $\begin{array}{l}++ \\
\dot{+} \\
+\end{array}$ & $\begin{array}{l}++ \\
+* \\
+\end{array}$ & $\begin{array}{c}t \\
++ \\
+\end{array}$ & $\begin{array}{l}+ \\
+ \\
+\end{array}$ & $\begin{array}{c}++ \\
+ \\
+\end{array}$ \\
\hline
\end{tabular}

* Type 22 enzymes degraded tapioca starch only.

Partially purified enzymes. Fractions precipitated by $25 \%$ methanol at pH 6.4 and $40 \%$ methanol at $\mathrm{pH} 4 \cdot 8$, and at $\mathrm{pH} 4 \cdot 2$, all showed hyaluronidase, amylase and non-specific depolymerizing activity. Active material remained in the supernatant after precipitation at $\mathrm{pH} 4 \cdot 2$, which was finally removed by increasing methanol concentration to 70\%. At first maximum activity was associated with the fraction precipitated at $\mathrm{pH} 4 \cdot 2$, but after repeated fractionation the main active material became progressively more soluble in methanol, and the best yield was recovered with $80 \%$ methanol which was left to stand at $-10^{\circ}$ for about 1 week. The available material was insufficient for adequate chemical analysis but appeared to be a water-soluble protein of low molecular weight. The relative activities of Type 4, Type 22 and Type 2 enzymes are indicated in Table 2. Results were reproducible for eleven filtrates, five Type 4 strains, three Type 22 strains, and three filtrates of one Type 2 strain.

\section{Activation of polysaccharidase components}

A Type 4 strain, H713, was grown for 2 days in conditions unfavourable for hyaluronidase and amylase production, namely in Neo-peptone filtered broth (1 1.) at $23^{\circ}$. The whole culture was treated with $\left(\mathrm{NH}_{4}\right)_{2} \mathrm{SO}_{4}$ to bring to $0 \cdot 7$ saturation. After standing overnight at $4^{\circ}$ the precipitate and cell debris were suspended in distilled water. The suspension was dialysed against running water for 2 days, and against glycerol for 1 day. The extract was free from viable organisms and had about one-fifteenth of the original volume. Graded dilutions in distilled water, sterile tap water or physiological saline were incu- 
bated overnight at $37^{\circ}$ after various additions. A Type 22 strain, P674, was grown in similar conditions, and material prepared in the same way.

Activation of amylase. Table 3 shows loss of activity after dialysis, restoration of $\beta$-amylase activity in salt solutions, and activation of $\alpha$-amylase after incubation with sodium sulphite enhanced by sodium $\beta$-glycerophosphate. The activation of amylase in these conditions was retarded by sodium salicylate. Active amylase-positive concentrates from Type 4 and Type 2 strains were also inactivated in the presence of salicylates in starch hydrolysis tests (Table 4).

Table 3. Activation of amylase by incubation of an inactive concentrate with sodium sulphite

Strain Hr13 ('Type 4) was grown for 2 days in filtered broth, the whole culture then precipitated by 0.7 saturation with $\left(\mathrm{NH}_{4}\right)_{2} \mathrm{SO}_{4}$. The precipitate was dialysed against tap water and then against glycerol. This glycerol concentrate was then examined as under. Before precipitation the culture supernatant had no $\alpha$-amylase activity, and the $\beta$-amylase titre was $1 / 8$ after $18 \mathrm{hr}$. incubation. Iodine test: $++++=$ achrojc point;,$+++++=$ erythrodextrins ( $\alpha$-amylase);,$+ \pm=$ blue deposit ( $\beta$-amylase). Recorded after 30 min. and $18 \mathrm{hr} .37^{\circ}$.

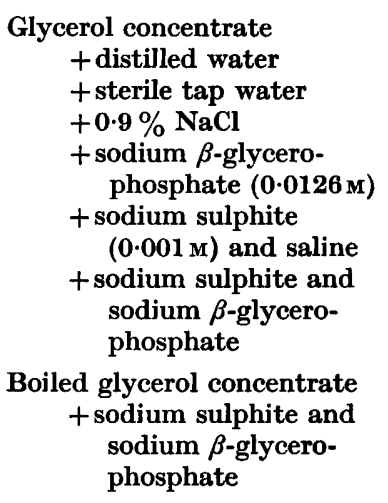

Hydrolysis of $\mathbf{0 . 2} \%$ soluble starch by final dilution of enzyme sample

\begin{tabular}{ccccc}
\hline $1 / 2$ & $1 / 4$ & $1 / 8$ & $1 / 16$ & $1 / 32$ \\
\pm & $\cdot$ & $\cdot$ & $\cdot$ & $\cdot$ \\
\pm & $:$ & \pm & $\cdot$ & $:$ \\
+ & + & \pm & \pm & $\cdot$ \\
+++ & ++ & + & \pm & \pm \\
+++ & ++++ & +++ & ++ & + \\
& & & &
\end{tabular}

\section{Table 4. Inactivation of amylase by sodium salicylate}

Results of iodine tests as in previous Tables.

H713 end-point titre of filtrate was $1 / 64,++$ reading, and equivalent to 12 units.

Hydrolysis of $0.2 \%$ soluble starch, $\left(30 \mathrm{~min}\right.$. at $\left.37^{\circ}\right)$ by final dilution of enzyme sample

Cell-free filtrates of strains H713 (Type 4) dilution in water H713 (Type 4) + Na salicylate (0.003 M) 4226 (Type 2) dilution in water 4226 (Type 2) + Na salicylate (0.003 $\mathrm{M})$

$\begin{array}{cccc}1 / 2 & 1 / 4 & 1 / 8 & 1 / 16 \\ ++++ & ++++ & ++++ & ++++ \\ \pm & \pm & \pm & \dot{+} \\ ++++ & ++++ & ++++ & ++\end{array}$

Hyaluronidase. The hyaluronidase activity of the same fraction was lost after dialysis. The M.C.P. titre was not increased after restoring salts nor after incubation with sodium sulphite. It also showed no increase after incubation 
with ascorbic acid $(0 \cdot 1-0 \cdot 01 \mathrm{M})$, boiled homologous organisms (washed and unwashed) and partially purified homologous hyaluronidase (1 M.C.P. unit). Material prepared from the Type 22 strain was tested in parallel with negative results.

Cell-free filtrates. The $\alpha$-amylase was activated by sulphite in an inactive cell-free filtrate of the same Type 4 strain, but the hyaluronidase titre was unaltered. Synovial fluid however became turbid, and the highest dilution showing precipitate as compared with the clear control was recorded as end-
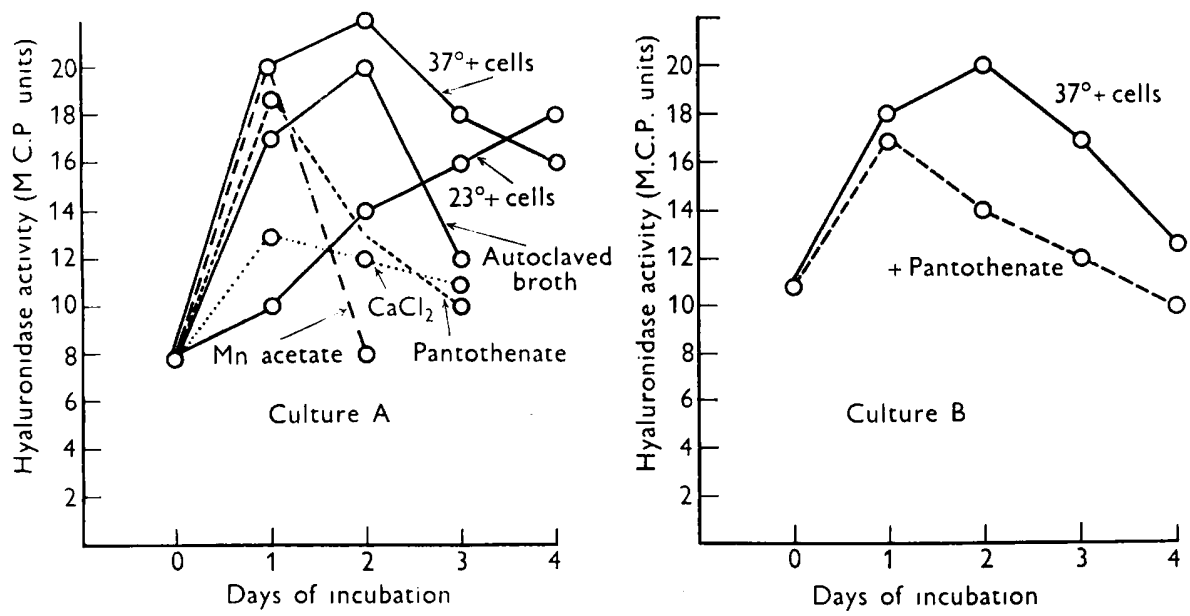

Fig. 3. Effect of pantothenic acid on an inactive cell free filtrate (strain Hr13, Type 4). Activators were added to graded volumes of filtrate (2-3 day culture at $\left.23^{\circ}\right)$. Neo-peptone autoclaved broth $=3 \mathrm{v} / \mathrm{v}$ unconcentrated and $\mathrm{v} / \mathrm{v}$ concentrate. Hyaluronidase was titrated after reincubation at $37^{\circ}$. (See text for concentrations.)

point. The turbidity titre was increased after incubation with sodium sulphite or sodium thiosulphate $(0.08 \mathrm{M})$, though the hyaluronidase titre was unchanged when measured by mucin-clot prevention. The 'turbidity' titre of a Type 22 filtrate was also increased after incubation with sodium sulphite, but the rise in titre was slight compared with the Type 4 filtrate in which the increase ran parallel to that of $\alpha$-amylase. Both Type 4 and Type 22 fractions caused flocculation and loss of viscosity in starch solutions after incubation with tap water, but the iodine test remained positive.

Traces of calcium, zinc, magnesium, copper and manganese salts were added to inactive filtrates which were incubated with and without sulphite. $\mathrm{ZnSO}_{4}$ $(0.0003 \mathrm{M})$ activated the $\beta$-amylase without the addition of sulphite. $\mathrm{CaCl}_{2}$ $(0.0025 \mathrm{M})$ increased $\alpha$-amylase activity, and gave maximum activity to a dialysed fraction in contrast to $\mathrm{NaCl}$, suggesting that both calcium ions and chloride ions were necessary for activation. Both calcium chloride and manganese acetate $(0.00004 \mathrm{M})$ caused a transient rise in M.C.P. titre (Fig. 3).

Neo-peptone autoclaved broth was frozen and about one-third of the original volume allowed to thaw. This concentrate added in equal volume to an inactive 
filtrate caused a rise in M.C.P. titre after overnight incubation equivalent to the usual increase of activity when inactive $23^{\circ}$ cultures were reincubated at $37^{\circ}$ in the presence of cells. The increased activity was only maintained for a few hours, and the filtrate lost all activity after further incubation.

Screening tests with different polymers. The specific requirements for different components were analysed by screening tests with other polysaccharide substrates. The predominant activities were placed in two groups:

depolymerase $I$, viscosity diminution, degradation of the molecule shown by flocculation, or $\beta$-amylase-type activity;

depolymerase II, increase of turbidity, clot prevention, loss of precipitability or $\alpha$-amylase type activity.

The artificial distinction was made for the purpose of the experiment, but approximates to the grouping made by Meyer (1947) and Rogers (1948). Table 5 shows the effect of different activators on components of depolymerase, comparing the activity of cell-free filtrates against several substrates.

Table 5. Activation of depolymerase: estimation of components by screening tests with several substrates

,$+ \pm=$ greater or lesser activity; $\mathrm{V}=$ loss of viscosity without changed iodine reaction; $I=$ physical change, flocculant precipitate, opalescence or turbidity; II = clot-prevention, turbidity changes with alcohol or acetone, or loss of iodine colour.

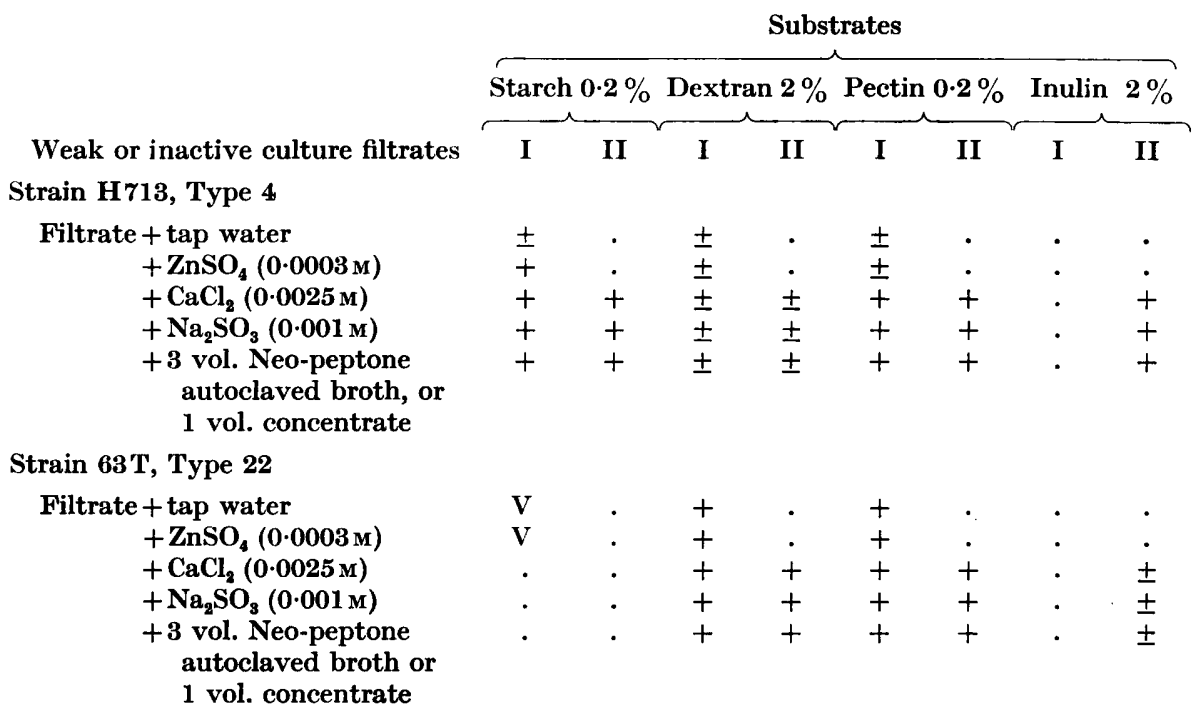

The addition of autoclaved Neo-peptone broth increased the activity of all components, lending support to the hypothesis of an enzyme-promoting factor made available by heating broth. Dole (1946), studying the effect of peptone on the growth of streptococci, reported that Neo-peptone (DIFCO) had a high calcium content. This suggested that the enzyme-promoting factor in the broth might be enhanced by calcium, explaining the superiority of Neo-peptone compared with Proteose peptone in increasing hyaluronidase production. 
The effect of pantothenic acid. Growth-promoting activity for Escherichia coli has been attributed to pantothenic acid conjugate in muscle extracts (King \& Cheldelin, 1950). Pantothenic acid (DL, calcium salt) was added to inactive filtrates $(2 \mathrm{~mm}$. loopful $0.02 \%(\mathrm{w} / \mathrm{v})$ to $10 \mathrm{ml}$. broth); the M.C.P. titre had increased after overnight incubation at $37^{\circ}$. The rise in titre was less than that after adding autoclaved Neo-peptone broth but greater than after adding $\mathrm{CaCl}_{2}(0.0025 \mathrm{M})$. An autoclaved pantothenate solution was less active. Activity after addition of $\beta$-alanine and $\gamma$-butyrolactone was not fully investigated. Fractions obtained by alcohol precipitation of filtered broth have so far failed to promote growth, and fractions of autoclaved broth, to promote enzyme production. There is no evidence at present to explain the effect of pantothenic acid.

\section{DISCUSSION}

The depressant effect of proteinase in high concentration on hyaluronidase may explain the variable activity of some Group A strains recorded by Meyer (1947). Proteinase activity by strains of the $T$ antigen groups 4, 24, 26, 28, 29 and 46 was associated with absence of polysaccharidase production (Crowley, 1950). Of Type 22 strains $90 \%$ had both proteinase and hyaluronidase activity, and the impression that different components predominated in the Type 22 enzyme was confirmed by screening tests against other polysaccharide substrates. The components designated depolymerase I, which catalyse viscosity diminution and degradation of the molecule, resemble phosphatases in activity. Since cell-free filtrates degraded five polymers it seems justifiable to conclude that the enzyme is a phosphatase of low specificity as suggested by Robertson, Ropes \& Bauer (1940). The activity of the second group of components resembled both hyaluronidase (estimated by turbidity change) and $\alpha$-amylase.

Sodium sulphite, which converted inactive precursor to amylase, also activates streptolysin $\mathrm{S}$ (Herbert \& Todd, 1944). The inactivation of amylase by salicylates raises several problems. Heparin inactivates both hyaluronidase (McClean, 1942) and amylase (Crowley, 1950). Calcium ions activate amylase and the anticoagulant effect of heparin has been attributed (among other factors) to the binding of calcium. The tentative identification of $\alpha$-amylase with one or more components of Type 4 hyaluronidase suggests that it may be premature to abandon the theory of anti-hyaluronidase activity by salicylates (Guerra, 1946), which Swyer (1948) believed to be due to contamination with histamine or a similar substance.

Though the role of pantothenic acid conjugate, of the free acid or its cleavage products in growth and enzyme promotion is not clear, it may be worth noting that Type 4 strains which lost polysaccharidase activity after serial mousepassage also lost ability to utilize high concentrations of yeast nucleic acid. It has been suggested that pantothenic acid is involved in purine metabolism besides being an essential growth factor for organisms which ferment carbohydrates (Baldwin, 1948).

In conclusion the non-specific depolymerizing activity of strains which degrade several polysaccharides was termed depolymerase to describe imperfectly defined activities in test conditions which were not necessarily optimal. 
I wish to thank Dr R. O. J. Clark, Dr P. Brown and Miss A. Demery, B.Sc. (Biochemistry Department, Royal Free Hospital), Dr R. A. Kekwick, Dr B. C. J. G. Knight, and Dr J. Corran (Chief Research Chemist, Reckitt and Colman, Ltd.) who gave me practical help and advice.

\section{REFERENCES}

Baldwin, E. (1948). Dynamic Aspects of Biochemistry, 2nd ed. Cambridge University Press.

Crowley, N. (1950). The degradation of starch by Group A streptococci having related antigens. J. gen. Microbiol. 4, 156.

Dole, V. P. (1946). A dialysate medium for the culture of Group A streptococci. Proc. Soc. exp. Biol., N.Y., 63, 122.

Eluiot, S. D. \& Dole, V. P. (1947). An inactive precursor of streptococcal proteinase. J. exp. Med. 85, 305.

Griffith, F. (1934). The serological classification of Streptococcus pyogenes. J. Hyg., Camb., 34, 542.

GuerRa, F. (1946). Hyaluronidase inhibition by sodium salicylate in rheumatic fever. Science, 103, 686.

Herbert, D. \& Todd, E. W. (1944). The oxygen stable haemolysin of Group A streptococci (Streptolysin S). Brit. J. exp. Path. 25, 242.

King, T. E. \& Cheldelin, V. H. (1950). Pantothenic acid studies. VIII. Growth of micro-organisms and counteraction of antimetabolites with pantothenic acid conjugate (PAC). J. Bact. 59, 229.

McClean, D. (1942). The in vivo decapsulation of streptococci by hyaluronidase. J. Path. Bact. 54, 284.

MEYER, K. (1947). The biological significance of hyaluronic acid and hyaluronidase. Physiol. Rev. 27, 3.

Quins, R. W. (1948). Studies of the mucin-clot prevention test for the determination of the anti-hyaluronidase titre of human serum. J. clin. Invest. 27, 463.

Robertson, W. van B., Ropes, M. W. \& Bauer, W. (1940). Mucinase: A bacterial enzyme which hydrolyses synovial fluid mucin and other mucins. J. biol. Chem. 133, 261.

Rogers, H. J. (1948). The complexity of bacterial hyaluronidases. Biochem. J. 42, 663.

Swift, H., Wilson, A. \& Lancefield, R. C. (1943). The typing of Group A streptococci by $M$ precipitin reactions in capillary pipettes. J. exp. Med. 78, 127.

SwYER, G. I. M. (1948). Anti-histamine effect of sodium salicylate and its bearing upon the skin-diffusing activity of hyaluronidase. Biochem. J. 42, 28.

Wittler, R. G. \& Pillemer, L. (1949). The solubility of equinal tetanal antitoxin in methanol-water mixtures of controlled $\mathrm{pH}$, ionic strength and temperature. J. Immunol. 62, 463. 